investigation where Fischer had left it, Sir James has carried the inquiry into the more complex field of the disaccharoses, and by means of new processes, which he has been able to evolve and apply, to assign definite chemical structures to many of these most important natural products. He has also studied the constitutions of the still more complex polysaccharoses, starch and inulin, incidentally gaining an insight into the manner in which the plant forms and utilises these fundamental reserve materials.

The Sylvester Medal: Prof. A. N. Whitehead.

Always primarily interested in the foundations of mathematics, it is in the logical analysis of these foundations that Prof. Whitehead's reputation has been won. The great work, "Principia Mathematica," written in collaboration with Bertrand Russell, contains the most systematic and the most profound analysis to which the foundations of the subject have yet been submitted.

From pure mathematics both Prof. Whitehead and his collaborator have turned independently to physics. In his more recent books Whitehead has endeavoured to apply the spirit of " Principia Mathematica," and in particular the principle which he calls "extensive abstraction," in the more complicated and more con- troversial field of physical existence. That a point, whether in the older physics or the modern physics of space-time, is a class, or a class of classes, of events, that an electron is a systematic correlation of the characters of all events throughout all Nature, are doctrines at which the unsophisticated may be tempted to scoff, but the tendency of modern scientific thought is to the conclusion that, if the world of physics is indeed ultimately capable of any rational interpretation, it must be interpreted in some such way.

The Hughes Medal: Mr. F. E. Smith.

Mr. Smith began work on the realisation of the fundamental units of electrical measurement in 1902 ; and such further experiments as have been made since have served only to confirm his results. Other important investigations by $\mathrm{Mr}$. Smith have dealt with the measurement of terrestrial magnetism. The recording magnetometers which he designed have proved of great value, while more recently he constructed, at the suggestion of Sir Arthur Schuster, a horizontal force magnetometer of extreme accuracy. During the War his services to the nation were of great importance, and since the Armistice, as Director of Research at the Admiralty, he has been responsible for a number of valuable investigations.

\title{
The Conference on Solid Smokeless Fuel in Sheffield.
}

A CONFERENCE on solid smokeless fuel was held $\mathrm{A}$ in the Department of Applied Science at the University of Sheffield on Friday November 2o. To point the moral, a tasty fog prevailed throughout the proceedings. The meeting was under the joint auspices of the Society of Chemical Industry, the Institution of Chemical Engineers, the Institution of Gas Engineers and the Midland Institute of Mining Engineers.

The objects of the meeting were to discuss methods of improving the quality of high-temperature coke and the alteration to present equipment and to plant which is required for the purpose. Dr. C. H. Lander contributed a general résumé, and papers were read by Dr. E. W. Smith on "The Qualities Requisite in a Solid Smokeless Fuel for Domestic Use," Prof. R. V. Wheeler on "The Production of Free-burning Solid Smokeless Fuel at High Temperatures," Mr. E. V. Evans on "The Combustibility and Reactivity of Coke," Mr. D. Rider on " Coke Quenching," and Mr. F. M. Birks on "Coke Handling, Screening and Breaking." There were about three hundred present, and the meeting was highly successful. In addition to the papers, investigations under the direction of Prof. Wheeler in the Fuel Department were inspected. There was also a demonstration of ordinary coke burning in open grates and in a closed one.

Low-temperature processes have been discussed with some thoroughness, and consequently the position as to these is fairly well known. Briefly, there is no low-temperature process. Many are the systems on paper, few are on works-sized concrete foundations, none show appreciable returns to the owners. It may be said of all, that none have mastered their engineering difficulties, few know even part of the chemistry of their products, whilst the efforts of all the systems have made no impression on the fuel question. It is clear that a low-temperature process will have to pass through the difficulties attending the evolution of the high-temperature process without any of the advantages attaching to these statutory bodies.

Such being the case, and assuming a demand for a free-burning solid smokeless fuel, can anything be done to render high-temperature coke more combust- ible and thus suitable for the domestic grate? If this can be done, then remembering that gas-works and coke-ovens together have an output of about 20 million tons of coke and that the domestic consumer consumes more than 40 million tons of coal per annum, the field for expansion is obvious. With regard to this scheme, it may be said that gas-works and coke-ovens do possess carbonisation technique, of a sort, capital has certainly been expended on them, they are old and tried servants.

If this were all, and provided high-temperature processes provide a free-burning fuel, then coke-ovens and gas-works have it. But it has yet to be proved that they can and will provide a coke that is easy to ignite, easy to keep alight, free from ash, low in moisture, clean and free from dust. But assuming that all this could be done and assuming that the combined output went to the domestic consumer - a very far-fetched assumption-only half of the domestic coal consumption would be displaced. A doubling of plant cannot reasonably be visualised within the next ten years.

Consequently there is still plenty of scope for lowtemperature carbonisation, if the processes could be put on a commercial footing. Considerable interest was taken in low-temperature processes owing to the probable oil obtainable under these conditions. But a good deal more oil seems probable by the use of hydrogenation methods, the one process being yet as problematical as the other. Little is known of the composition of the liquid products of low-temperature processes. It is for this reason that low-temperature processes are desirable. It may well be that new classes of compounds may be brought to light with new properties and new uses. New drugs, new dyes, may be obtained, new substances with yet unknown benefit to mankind. Whatever the financial results from low temperature, the probable scientific results should be known.

The technical contributions to the subjects of the conference may be summed up in a short space, as was done by Prof. Wheeler. Fine grinding followed by blending, and the mixture of coals thus produced to be carbonised in narrow ovens under high-tempera-

NO. 2927 , VOL. I I 6$]$ 
ture conditions, the charge to be pushed when the centre of the coke reaches $700^{\circ} \mathrm{C}$., seem likely to produce a more combustible coke. This opinion is based on some theory, on a fair amount of careful laboratory experiments, with but little large-scale confirmation, however.

Of scientific contributions there were naturally few; naturally, because of the newness, vastness and difficult character of the field. Concerning carbonisation, profound ignorance prevails. As to treatment and events beyond the hydraulic main there is still room for discussion-witness the recent contribution to this by Dr. Smith and Mr. Finlayson-but in respect to treatment and events, from the cold coal to the hydraulic main, there is no useful discussion. We do not know. There is much methane in coal gas; the methane has presumably been at $1000^{\circ} \mathrm{C}$. or so. At this temperature methane deposits carbon and produces hydrogen. The shiny carbon-termed methane carbon-is accompanied by at least two, if not more than two, physically different forms of carbon. Moreover, from the deposit, it is almost as easy to pick out pieces of naphthalene as it is pieces of carbon.

At the Conference the terms reactivity and combustibility were used as synonyms. Korrevar has shown that they are as synonymous as silica and glass. Mr. E. V. Evans brought forward a new method for the determination of the combustibility of coke, as regards the utility in the open grate, and the method promises much. But as to reactivity, that intrinsic property of carbon, not much was said. The reactivity of carbon, which lies at the basis of the combustibility of that impure substance, coke, depends on the physical condition of the carbon, and at once we are back to the carbon deposits from methane cracking. If we know nothing concerning these deposits carbon, what are we to say of our real knowledge of coke?

As Dr. H. M. Travers pointed out, at almost every stage of the carbonisation some very pertinent and unanswerable questions may be put. Why is primary tar formed at all-what is the mechanism of it? Why does coke at the later stages of carbonisation evolve hydrogen for the most part, and that in bursts with rise of temperature? He also put in a plea for research into fundamentals of fuel utilisation ; if this be undertaken, then the Conference may well be a momentous one. $\mathrm{He}$ considers that the universities should undertake the work rather than, for example, the Fuel Research Board. His opinion is that progress is not likely to follow the permutations and combinations of well-known works processes. A difficulty is created, however, by the financial position of most of the universities of Great Britain. Many public-spirited industrialists know this, and there may be those, whether individuals or corporations, who would care to contribute towards the cost of research into fundamentals of this character.

Should means become available for the prosecution of the fundamental researches indicated, then a plea might be entered for the University of Sheffield, where there is a well-established school of fuel research. The list, distributed at the meeting, of work in progress, served to indicate the varied and extensive character of its activities. One could pass from Fuel Research Board apparatus, solvent resolution, to spontaneous combustion, momentary heating of coal, desulphurisation, combustion, coal constitution, synthetic ulmins, hydrogenation, flame work and microscopic work.

The Conference adjourned until February for a meeting at Manchester.

S. L. B. Etherton.

\section{The Early Nilotic, Libyan, and Egyptian Relations with Minoan Crete.}

THE Huxley Memorial Lecture of the Royal Anthropological Institute for I925 was delivered by Sir Arthur J. Evans at the rooms of the Royal Society on Tuesday, November 24. The chair was taken by Prof. C. G. Seligman, president of the Institute.

Sir Arthur Evans said Crete might be described as a half-way house between three continents, Europe, Asia, and Africa. Its fortunate situation marked it as the point where the primitive culture of our continent was first affected by the older civilisations of Egypt and the East. The most ancient geographical relations of Crete lay with Anatolia and the East. Man entered 'Crete from the Anatolian side; he may even have found the dwarf hippopotamus surviving from the times of the land-bridge of Miocene and Pleistocene times; but Palæolithic discoveries in Crete are still wanting and human remains from Neolithic times are still to seek. From Middle Minoan times a brachycephalic element is perceptible, mixed with the older dolichocephalic inhabitants, which may be due to an intrusion of "Armenoids" from Asia Minor, for which a portrait on a Middle Minoan seal supplies an argument. Archæological, religious, and linguistic evidence all point to a root connexion between Crete and Anatolia. The primitive female steatopygous figures from the Neolithic strata of Knossos find remarkable parallels from Asia Minor and so far afield as the Euphrates and Caspian. Stone maces and monochrome pottery show similar affinities. The pre-Hellenic language is related to old Carian and its kindred tongues.

It has been supposed that Egyptian relics found in connexion with Minoan and Mycenæan Crete arrived by the Syrian or Anatolian route, but this is unsupported by any evidence as regards the earlier contact of Crete with the Nile Valley. There is abundant proof that early man was not averse from deep-sea voyages. It is natural to suppose that in the East Mediterranean navigation began in the Egean island world. Neither the Syrian nor the Libyan coast was favourable to its rise. Of Cretan vessels, the earliest representation is a clay model from Palaikastro of the First Early Minoan Period, which may be compared with the Nile craft such as those shown on the pottery of Naqada. There was a general use of sailing craft from an early date, and vessels with a single mast are of constant recurrence at the beginning of the Second Early Minoan Period in the first half of the third millennium B.C.

Evidence accumulating since 1890 of early relations between Crete and Egypt going back to the fourth Dynasty received remarkable confirmation from the beginning of the excavations at Knossos, in the form of imported Egyptian stone vessels of late prehistoric and protodynastic age and, more important, in derivative native Cretan forms in softer stone such as steatite and serpentine. In a Neolithic house of rectangular form found under the Central Court of the original Palace of Knossos, with fixed hearth of Anatolian type, was found among objects of pure Stone Age tradition a copper axe which must be regarded as an importation, not improbably from the Nile Valley. Two finds of special importance from this site were a gallipot-like vessel with clear traces of tubular drilling closely resembling a type of late predynastic and protodynastic Egyptian vessels, and two fragments of vessels of variegated stone which, 